Ibn Al-Haitham Jour. for Pure \& Appl. Sci. 34 (1) 2021

Ibn Al Haitham Journal for Pure and Applied Science Journal homepage: http://jih.uobaghdad.edu.iq/index.php/j/index

\title{
Study the Effect of Annealing on the Structural Properties of Zinc Oxide Films by Electrolysis Technique
}

\author{
Aws A. Mahdi \\ Sameer A. Makki \\ Department of Physics, College of Education for Pure Science (IbnAl-Haitham),University of \\ Baghdad, Baghdad, Iraq. \\ ausalimahdi1994@gmail.com \\ Article history: Received,19, December ,2019, Accepted 27,April,2020, Published in January 2021
}

Doi: 10.30526/34.1.2574

\begin{abstract}
Zinc oxide films $(\mathrm{ZnO})$ are prepared by an electrolysis technique and without vacuum and then annealed atvarious temperatures $(300,400,500)^{\circ} \mathrm{C}$ for an hour. The structural analysis performed by X-Ray diffraction (XRD) shows,dominant orientation of this films is plane (101), has a hexagonal structure and polycrystalline pattern and it was is found that the crystal size increases $(24,29) \mathrm{nm}$ at annealing temperatures $(300,400)^{\circ} \mathrm{C}$, but the crystal size decreases to $(20 \mathrm{~nm})$ at annealing temperature $\left(500^{\circ} \mathrm{C}\right)$. As the results of a surface nature study of these films showed by examining the atomic force microscope (AFM), the grain size increases from (60.79 to 88.11) nm, and the surface roughness increases from (1.99 to 2.34) $\mathrm{nm}$ when increasing annealing temperatures is $(300,400,500)^{\circ} \mathrm{C}$, respectively.
\end{abstract}

Keywords: thin film, $\mathrm{ZnO}$, electrolysis, annealing temperature.

\section{Introduction}

Zinc oxide $(\mathrm{ZnO})$ is a semiconductor compound of the II-VI family, [1]. Zinc has characteristics such as the presence of an optical energy gap $(3.37 \mathrm{eV})$ and a large exiton binding energy $(60 \mathrm{meV})$ at room temperature [2,3]. Where it has absorbance, it is located in the UV zone and has good conductivity at n-type[4]. It has another property that can be polycrystalline or single crystal films and even random, in a random order if the films are exposed to a temperature of less or equal to $(180)^{\circ} \mathrm{c}$, to consider this degree is the degree of critical material $[5,6]$. When exposed to heating in the air (without vacuum ), change color for ( Zno) compound from white to yellow color, When cooling, the compound returns to white color again, This is due to the loss of a few number of oxygen at high temperatures [7]. As well as not dissolving in water or alcohol, the compound may be soluble in certain 
acids, namely acetic acid and mineral acids, etc .[8]. Zinc Oxide films are used for the manufacture of certain devices, including condensers, solar cells, gas sensors, purple and blue light emission devices and pressure sensors [9,10]. Zinc oxide films prepared with various techniques are spray pyrolysis[11], magnetron sputtering [12], electron beam evaporation [13], sol-gel coating[14] and chemical vapor deposition [15] .In this search, the effect of annealing temperatures $(300,400 \text { and } 500)^{\circ} \mathrm{C}$ on the structural properties of zinc oxide films has been identified.

\section{Experimental Procedure}

1-The hydrochloric acid is diluted by adding $(10 \mathrm{ml})$ of acid to $(90 \mathrm{ml})$ of distilled water .

2-This diluted solution is placed in a beaker and considered an electrolyte solution.

3- Two slides of zinc are immersed in the electrolyte solution and the first slide is connected to the positive electrode of the source and the other slide to the source electrode

4-passing an electric current with a value of $((\mathrm{I}=127 \mathrm{~mA})$, voltage $(5 \mathrm{~V})$, and the distance between the two slides $(\mathrm{d}=1.5 \mathrm{~cm})$.

5- The time taken to prepare the solution is $(10 \mathrm{sec})$.

6-by drop casting method, it is deposited on the glass slides and then annealed these films at different temperatures $(300,400,500)^{\circ} \mathrm{C}$ for an hour.

\section{Results and Discussion}

\subsection{X-ray diffraction}

By examining the $\mathrm{X}$-ray diffraction, it was found that the $\mathrm{ZnO})$ films had a polycrystalline structure of hexagonal type when compared with the International Center for Diffraction Data for zinc oxide. Measurements found that the dominant peak of this film is plane(101), and it was found that the highest intensity is at the plane (101), i.e. direction perpendicular to the base, and this tendency in crystallization was due to the van der Drift model called the Survival of the fastest model, as suppose the process of nucleation is established has more than one direction in the first stages of the film growth, then these trends began to compete during its growth, so the faster nuclei will continue to grow, while the growth of the other nuclei stops, and this explains the growth of the $\mathrm{ZnO}$ membranes towards (101), i.e. direction perpendicular to the base, because this the trend is the fastest growing, , And the intensity increases when the annealing temperature increases between $(300,400){ }^{\circ} \mathrm{C}$, but the intensity decreased at the temperature $\left(\left(500^{\circ} \mathrm{C}\right)\right.$ and this means a decrease in crystalline regularity, as well as a decrease in the value of the Full Width at Half Maximum purpose $(\beta)$ at annealing temperature $(300,400)^{\circ} \mathrm{C}$ and increased at annealing temperature $\left(500^{\circ} \mathrm{C}\right)$, as shown in Figure 1 and Table 1 
Ibn Al-Haitham Jour. for Pure \& Appl. Sci. 34 (1) 2021

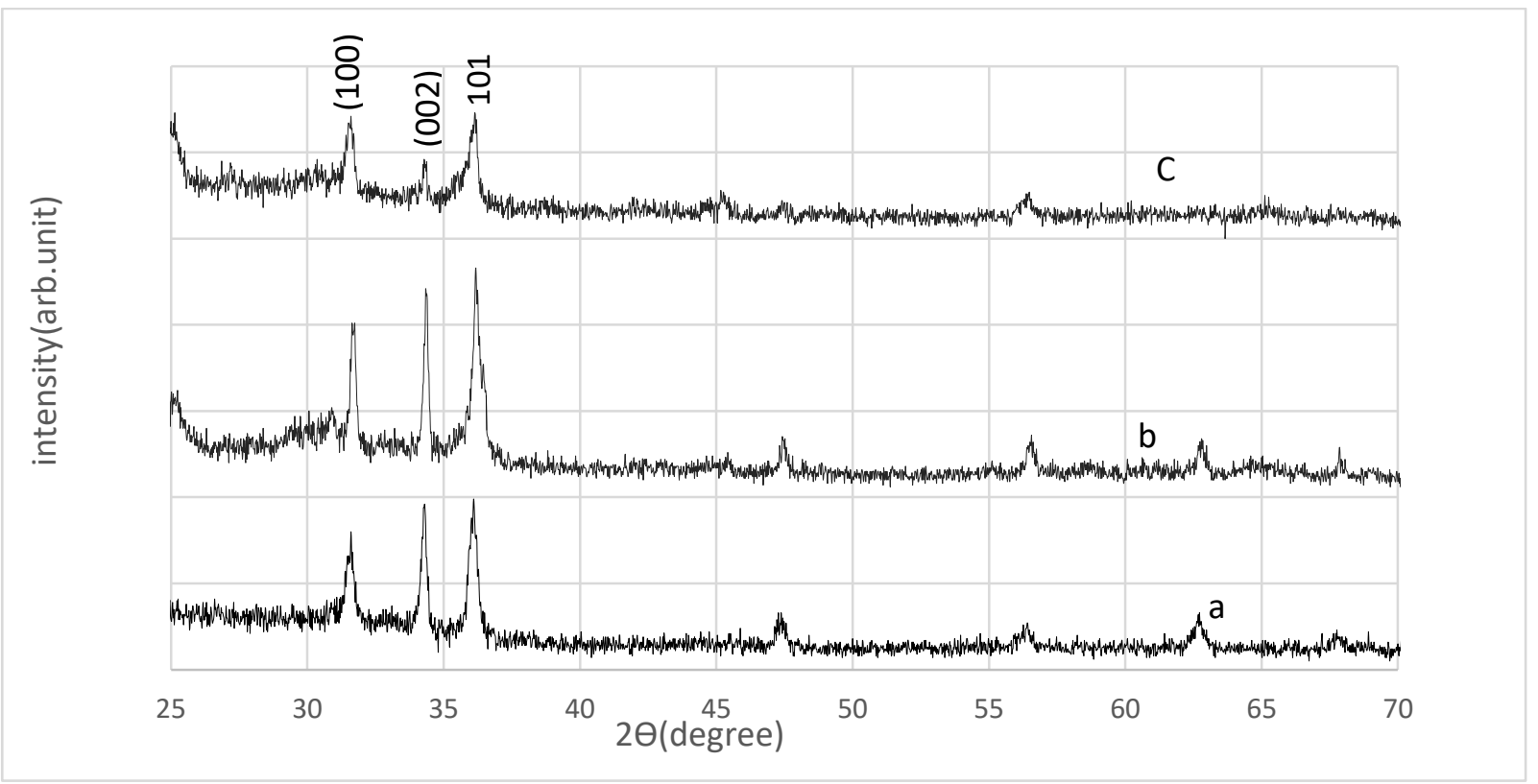

Figure 1.Represents the X-ray diffraction patterns of the annealed zinc oxide films at different temperatures a $\left(300^{\circ} \mathrm{C}\right) \mathbf{b}\left(400^{\circ} \mathrm{C}\right) \mathbf{c}-\left(500^{\circ} \mathrm{C}\right)$

Table 1 shows the distance between the planes and the X-ray diffraction angle values for the crystalline planes $(101,002,100)$ at the different annealing temperatures.

\begin{tabular}{|c|c|c|c|}
\hline Sample & $2 \theta$ (degree) & $d(h k l) A^{0}$ & $(\boldsymbol{h k l})$ \\
\hline ZnO (ICDD) & $\begin{array}{l}36.2521 \\
34.4211 \\
31.7694\end{array}$ & $\begin{array}{l}2.475920 \\
2.603320 \\
2.814300\end{array}$ & $\begin{array}{l}(101) \\
(002) \\
(100)\end{array}$ \\
\hline $\mathrm{ZnO}$ at $300^{\circ} \mathrm{C}$ & $\begin{array}{l}36.0867 \\
34.2936 \\
31.5734\end{array}$ & $\begin{array}{l}2.48695 \\
2.61277 \\
2.83139 \\
\end{array}$ & $\begin{array}{l}(101) \\
(002) \\
(100)\end{array}$ \\
\hline $\mathrm{ZnO}$ at $400^{\circ} \mathrm{C}$ & $\begin{array}{l}36.2333 \\
34.3901 \\
31.7153\end{array}$ & $\begin{array}{l}2.47723 \\
2.60566 \\
2.81905\end{array}$ & $\begin{array}{l}(101) \\
(002) \\
(100)\end{array}$ \\
\hline $\mathrm{ZnO}$ at $500^{\circ} \mathrm{C}$ & $\begin{array}{l}36.0955 \\
34.3235 \\
31.5914\end{array}$ & $\begin{array}{l}2.48637 \\
2.61056 \\
2.82982\end{array}$ & $\begin{array}{l}(101) \\
(002) \\
(100)\end{array}$ \\
\hline
\end{tabular}


Ibn Al-Haitham Jour. for Pure \& Appl. Sci. 34 (1) 2021

\section{3-1-1 Synthetic properties parameters}

1-A distance between crystalline planes

The distance between the crystalline planes was calculated and compared with the zinc oxide international card, and it was found to be close.The reason for this difference between the international card and the results is, firstly, the oxygen deficiency (away from the chemical equivalence) and, secondly, the effect of stress due to the thermal expansion coefficient of the membrane $\left(7 \times 10^{-6} /{ }^{\circ} \mathrm{C}\right)$ and the thermal expansion coefficient of the glass base $\left(4.6 \times 10^{-6} /{ }^{\circ} \mathrm{C}\right)$ are incompatible, and the value of the distance between atomic planes (d) we found to decrease at the annealing temperatures $(300,400)^{\circ} \mathrm{C}$ but increase at the temperature of $\left(500{ }^{\circ} \mathrm{C}\right)$, as shown in Table 1 . 2- Crystalline lattice constants

The crystal lattice constants $\left(a_{0}, c_{o}\right)$ for the zinc oxide films prepared in this waywere found to be close to the International Card. (ICDD). At the annealing temperature $(300,400){ }^{\circ} \mathrm{C}$ we found that it decreased but increased at the annealing temperature of $500{ }^{\circ} \mathrm{C}$. As shown in Table 2

Table 2.the values of the crystal lattice constants (ao, co) at temperatures $(300,400,500)^{\circ} \mathrm{C}$, respectively.

\begin{tabular}{|c|c|c|c|c|}
\hline Sample & $\mathrm{a}_{\mathrm{o}}\left(\mathrm{A}^{0}\right)$ & $\mathrm{C}_{\circ}\left(\mathrm{A}^{0}\right)$ & $\mathrm{d}_{\mathrm{hkl}}\left(\mathrm{A}^{0}\right)$ & $(\mathrm{hkl})$ \\
\hline $\mathrm{ZnO}(\mathrm{ICDD})$ & 3.24967 & 5.20664 & 2.603320 & $(002)$ \\
& & & 2.814300 & $(100)$ \\
\hline $\mathrm{ZnO}$ at 300C & & 5.2254 & 2.61277 & $(002)$ \\
& 3.269 & & 2.83139 & $(100)$ \\
\hline $\mathrm{ZnO}$ at $400 \mathrm{C}^{0}$ & 3.2551 & 5.21132 & 2.60566 & $(002)$ \\
& & & 2.81905 & $(100)$ \\
\hline $\mathrm{ZnO}$ at $500 \mathrm{C}^{0}$ & 3.26759 & 5.22112 & 2.61056 & $(002)$ \\
& & & 2.82982 & $(100)$ \\
\hline
\end{tabular}

\section{3-crystalline Size}

The crystal size of the zinc oxide films was calculated and it was found that crystal size increased with increasing annealing temperatures $(300,400)$ and the reason for increasing of the crystal size is a decrease (FWHM) because the relationship between them is inverse and the effect of annealing temperature led to the abolition of some planes and defects that exist after the growth and rearrangement of the crystalline grains takes place, as the granules take sufficient energy for growth and arrangement within the crystalline lattice, but I have decreased at the annealing temperature $\left(500^{\circ} \mathrm{C}\right)$. This led to an increase in crystalline defects and consequently a decrease in crystal sizer as shown in Table 3. 
Ibn Al-Haitham Jour. for Pure \& Appl. Sci. 34 (1) 2021

Table 3.shows Full Width at Half Maximum values and grain size

\begin{tabular}{|l|l|l|l|l|}
\hline Sample & $2 \Theta($ degree $)$ & $\beta=F W H M($ degree $)$ & $D_{\text {av }}(\mathrm{nm})$ & hkl \\
\hline $\mathrm{ZnO}$ at $300 \mathrm{C}^{0}$ & 36.0867 & 0.37160 & 24 & 101 \\
\hline $\mathrm{ZnO}$ at $400 \mathrm{C}^{0}$ & 36.2333 & 0.30690 & 29 & 101 \\
\hline $\mathrm{ZnO}$ at $500 \mathrm{C}^{0}$ & 36.0955 & & & 101 \\
& & 0.45070 & 20 & \\
\hline
\end{tabular}

\section{3-2 Atomic Force Microscopy}

By examining the (AFM) to investigate the surface topography (nature) we know the effect of annealing at various temperatures is $(300,400,500)^{\circ} \mathrm{Con}$ zinc oxide films and as shown by the grain size and surface roughness, we found that the granular size values increase within the nanoscale range $(60.79-88.11) \mathrm{nm}$, and an increase in the surface roughness values (1.992.34) $\mathrm{nm}$, which leads to an increase in absorbance. This indicates the possibility of using these films in the manufacture of solar cells, as shown in Table $\mathbf{4}$ and Figure 2.

Table 4. Grain size and roughness values for the surface of zinc oxide films at different annealing temperatures $(300,400,500){ }^{\circ} \mathrm{C}$.

\begin{tabular}{|l|l|l|l|}
\hline Sample & Average diameter(nm) & Roughness surface(nm) & $\begin{array}{l}\text { Root mean } \\
\text { square(nm) }\end{array}$ \\
\hline $\mathrm{ZnO}$ at $300{ }^{\circ} \mathrm{C}$ & 60.79 & 1.99 & 2.3 \\
\hline $\mathrm{ZnO}$ at $400{ }^{\circ} \mathrm{C}$ & 70.68 & 2.14 & 2.5 \\
\hline $\mathrm{ZnO}$ at $500^{\circ} \mathrm{C}$ & 88.11 & 2.34 & 2.83 \\
\hline
\end{tabular}

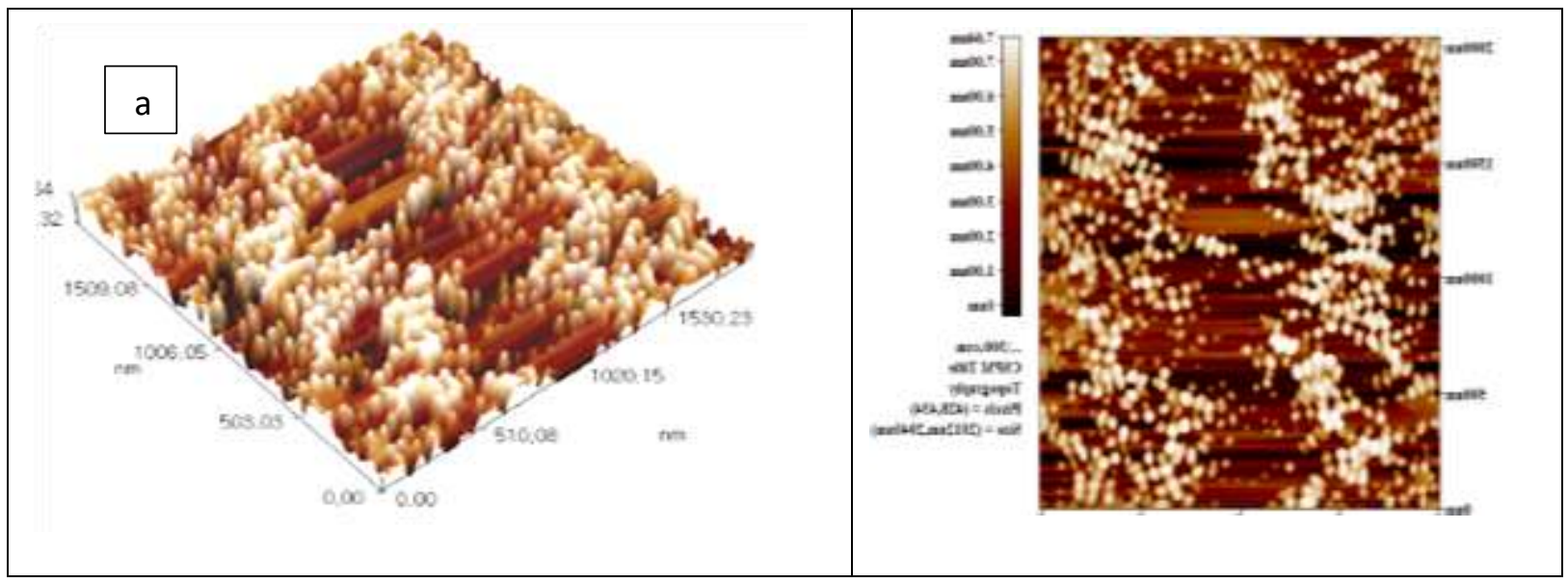




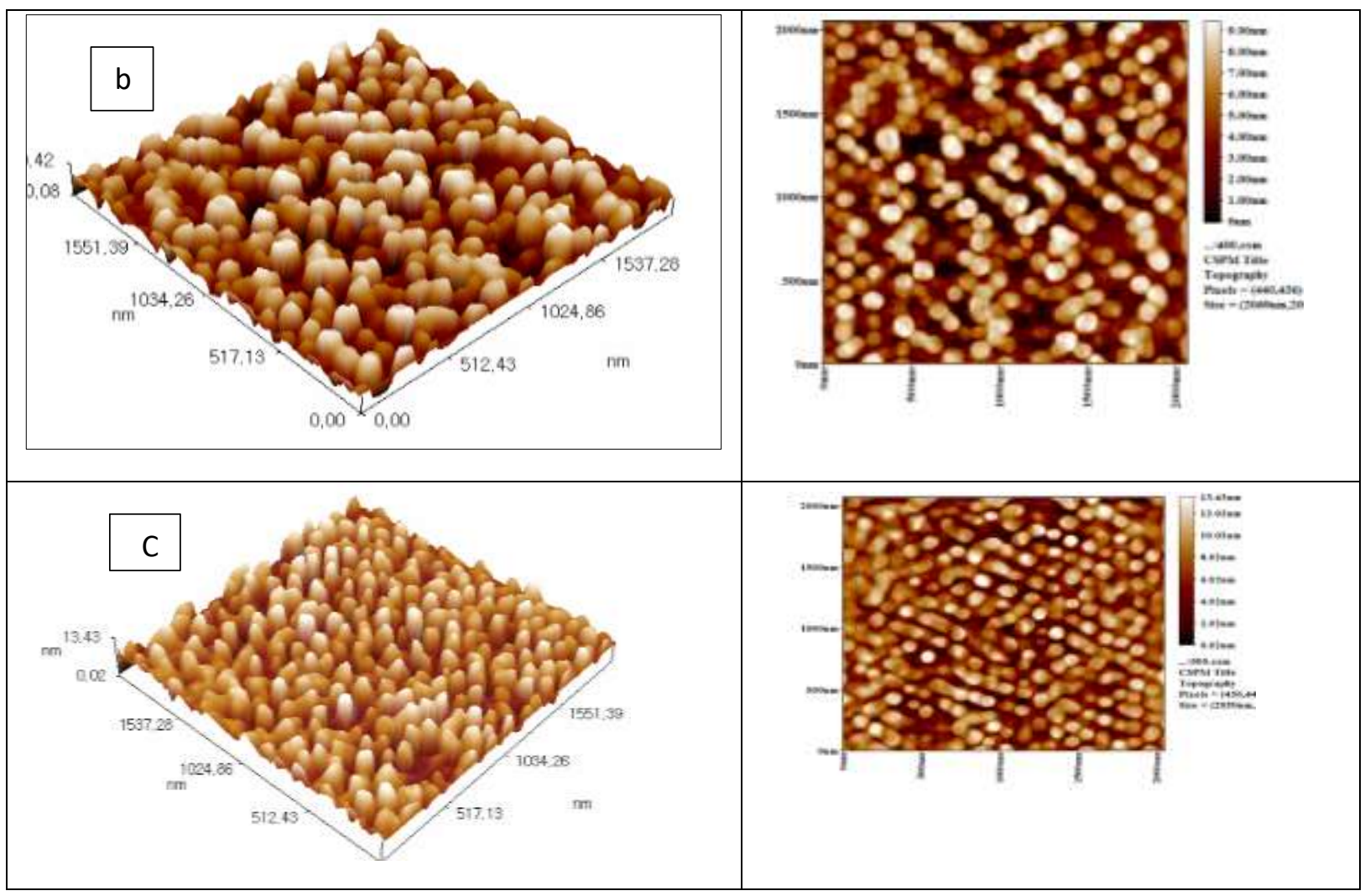

Figure 2 .Results of examination of the atomic force microscopy of the zinc oxide films at different annealing temperatures a- $\left(300^{\circ} \mathrm{C}\right) \mathbf{b}-\left(400{ }^{\circ} \mathrm{C}\right) \mathbf{C}\left(500^{\circ} \mathrm{C}\right)$.

\section{Conclusions}

The zinc oxide films show that the dominant direction is plane(101). When the annealing temperature increases to $500 \mathrm{C}$, this intensity decreases at this temperature, and this means the membranes have decreased degree of crystallization. It is found that when the annealing temperature increases, the surface roughness increases and the absorption increases, making the membranes good to use as a solar cell.

\section{Reference}

1.You, JB, Zhang XW, Fan YM, Yin ZG, Cai PF, Chen NF. Effects of crystalline quality on the ultraviolet emission and electrical properties of the $\mathrm{ZnO}$ films deposited by magnetron sputtering. Applied surface science. 2009, Mar 15;255,11,5876-80.

2. Kammler, D.R.,; Edward, D.D. Edward; Ingraw, B.G.; Mason, T.O. Novel compound and soild solution transparent conducting oxides for photovoltaic, Journal electrochemical society proceeding., 2000, 99, 68.

3. Hsu, YW.; Li HC.; Yang YJ; Hsu, CC. Deposition of zinc oxide thin films by an atmospheric pressure plasma jet. Thin Solid Films. 2011 Mar 1;519(10):3095-9.

4.FalihK, R. (2004) .Falih. A study of the optical and electrical properties of Zno oxide films prepared by the method of thermal evaporation in a vacuum. Master Thesis, Al-Mustansiriya University, College of Science. 2004. 
5.Nakagawa, T.; Matsumoto, K.; , I.; Uematsu, M.; Haneda, H.; Ohashi ,N. Analysis of indium diffusion profiles based on the Fermi-level effect in single-crystal zinc oxide. Japanese Journal of Applied Physics. 2008 Oct 17;47(10R):7848.

6. Al-Jabiry, AJ. Studying the effect of molarity on the physical and sensing properties of zinc oxid thin films prepared by spray pyrolysis technique, (Doctoral dissertation, Ph. D. thesis, University of Technology).

7. Chopra, KL.; Kaur, I. Thin film phenomena. New York: McGraw-hill; 1969.

8.Esraa, A. ; Nader, F. Fad Haboubi, 2015. Structural and optical properties of (ZnO: Bi) films prepared by the chemical pyrolysis method. Journal of the College of Education, 2015 ,1, 9-34.

9. Olvera, MD.; Gomez, H.; Maldonado, A. Doping, vacuum annealing, and thickness effect on the physical properties of zinc oxide films deposited by spray pyrolysis.Solar Energy Materials and Solar Cells. 2007 Sep 22;91(15-16):1449-53.

10.Maiti, UN.; Ghosh, PK,; Nandy, S.; Chattopadhyay, KK. Effect of Mn doping on the optical and structural properties of $\mathrm{ZnOnano} /$ micro-fibrous thin film synthesized by sol-gel technique.Physica B: Condensed Matter. 2007 Jan 1;387(1-2):103-8.

11.Elmas, S.; Ozcan, S.; Ozder, S. ; Bilgin, V., Influence of annealing temperature on the electrical and optical properties of CdS thin films. Displays. 2012. 4, 6.

12.Yu, JH.; Yang, HJ.; Mo HS; Kim, TS; Jeong, TS.; Youn, CJ.; Hongb, KJ. Rapid-thermal post-annealing effect of room-temperature grown $\mathrm{ZnO}$ : $\mathrm{Ga}$ layers by the radio-frequency cosputtering. Journal of Ceramic Processing Research. 2013 Jan 1;14(6):667-72.

13.Kuroyanagi, A. Properties of aluminum-doped $\mathrm{ZnO}$ thin films grown by electron beam evaporation. Japanese journal of applied physics.1989 Feb;28(2R):219..

14.Razak, A.F.A.; Devadason, S.; Sanjeeviraja, C.; Swaminathan, V.; Effect of annealing on structural and optical properties of $\mathrm{ZnO}$ thin films by sol gel technique. Chalcogenide Letters. 2011, 8,9, 511519.

15. Khallaf, H.; Chai, G.; Lupan, O.; Heinrich, H.; Park, S.; Schulte, A.; Chow, L. Investigation of chemical bath deposition of $\mathrm{ZnO}$ thin films using six different complexing agents. Journal of Physics D: Applied Physics. 2009 Jun 17;42(13):135304. 